\title{
Adhesion to pharyngeal epithelium and modulation of immune response: Lactobacillus salivarius AR809, a potential probiotic strain isolated from the human oral cavity
}

\author{
G. C. Jia, ${ }^{1 *}$ N. Che,${ }^{2 *}$ Y. J. Xia, ${ }^{1}$ Phoency F.-H. Lai, ${ }^{1}$ Z. Q. Xiong, ${ }^{1}$ G. Q. Wang, ${ }^{1}$ H. Zhang,${ }^{1}$ and L. Z. Ai ${ }^{1} \dagger$ \\ ${ }^{1}$ Shanghai Engineering Research Center of Food Microbiology, School of Medical Instrument and Food Engineering, \\ University of Shanghai for Science and Technology, Shanghai 200093, China \\ ${ }^{2}$ Department of Otolaryngology, Tongji Hospital, Tongji University, Shanghai 200065, China
}

\section{ABSTRACT}

Microbiome modulators such as probiotics are known to modulate oral diseases. Very few probiotics are commercially available for use in the oral cavity. In this context, we selected human-origin Lactobacillus salivarius AR809 as a promising oropharyngeal probiotic and characterized its functional and immunomodulatory properties. Results demonstrated that AR809 could efficiently adhere to pharyngeal epithelial FaDu cells, antagonize Staphylococcus aureus, adapt to the oral environment, and modulate host innate immunity by inducing potentially protective effects. Particularly, AR809 diminished proinflammatory activity by enhancing the production of $I L 10$ and inhibiting the expression of tumor necrosis factor- $\alpha, I L 1 B$, inducible nitric oxide synthase, and RELA. Finally, we observed that AR809 grew efficiently when cultured in milk, suggesting that the preparation of a fermented milk product containing AR809 could be a practical way to administer this probiotic to humans. In conclusion, AR809 has high potential to adhere to the pharyngeal mucosa and could be applied in novel milk-based probiotic fermented food products.

Key words: Lactobacillus salivarius, pharyngeal epithelium, functional property, milk

\section{INTRODUCTION}

The oral cavity harbors hundreds of microbial species (Keijser et al., 2018); most are normal or commensal microbes and some are beneficial bacteria with oral mucosal barrier functions, conferring resistance to pathogen colonization and modulating the immune system of the host (López-López et al., 2017). However,

Received December 7, 2018.

Accepted April 15, 2019.

*These authors contributed equally to this work.

†Corresponding author: ailianzhong@hotmail.com the oropharyngeal microbiota is a diverse and dynamic system (Lamont et al., 2018). Various uncertain risk factors (i.e., host susceptibility, poor oral hygiene, or dietary habits) can modify the oral microbiota, altering the natural balance between commensal and pathogenic microorganisms (Esteban-Fernández et al., 2018; Fan et al., 2018). These aberrations result in predominance of opportunistic pathogens in the oral cavity, causing bacterial infections such as pharyngitis, halitosis, caries, periodontitis, gingivitis, and other oral diseases (Amer et al., 2017; Gao et al., 2018). Hence, approaches to restore or replenish the composition and function of the normal oral microbiota are very important. The same benefit can be achieved using probiotics (Singh et al., 2018).

Probiotics are nonpathogenic microorganisms, which when consumed in adequate amounts can confer a positive health benefit on the host (FAO/WHO, 2006). They exert their key functions through immune-regulatory actions, thereby modifying host's immune system, by restoring gut barrier function, by lowering intestinal $\mathrm{pH}$, by decreasing colonization and invasion by pathogenic organisms, and by the production of favorable metabolic products through modulation of the gut microbiota (Son et al., 2019). Recently, studies have indicated that probiotics can modify the oral microbiota, and many are under investigation to prevent or treat diseases of the oral cavity, such as dental caries and periodontal diseases (Krzyściak et al., 2017; Invernici et al., 2018; Lin et al., 2018). Such diseases are associated with a shift in the microbial composition and activity of biofilm and the resulting reaction of the host (Allaker and Stephen, 2017). Several probiotics have been designed for the oral cavity (Ai et al., 2017; Rungsri et al., 2017). The use of probiotics in the oropharyngeal tract is particularly promising. Oral pathogens such as Staphylococcus aureus, group A streptococci, and Porphyromonas gingivalis often cause microbial dysbiosis and result in oropharyngeal tract dysfunctions (Schenck et al., 2016; Blasco-Baque et al., 2017). Therefore, the 
oropharyngeal tract is a potential target for developing new, specifically designed probiotic products.

Wescombe et al. (2006) isolated Streptococcus salivarius strain K12 from the oral cavity; this strain showed high adhesive ability and inhibitory activities against oral pathogens. The strain was used to create probiotic food products (powder and chewing gum), commercialized under the name of BLIS K12 (BLIS Technologies, Dunedin, New Zealand), specifically for prevention or treatment of dysfunction such as tooth decay, periodontitis, bad breath, and pharyngitis ( $\mathrm{Zu}-$ pancic et al., 2017). The United States Food and Drug Administration has assigned the oral probiotic product BLIS K12 "generally recognized as safe" (GRAS) status, which allows the probiotic to be used as a food additive (Taverniti et al., 2012). To our knowledge, no other probiotics for the oral cavity are commercially available except Streptococcus salivarius K12 and Streptococcus salivarius M18. Isolation and characterization of new strains are needed.

The objectives of this study were to (1) select the oral isolate Lactobacillus salivarius AR809 as a new probiotic candidate for the pharyngeal mucosa and analyze its potential probiotic properties in vitro; (2) assess the responses induced by AR809 in RAW264.7 macrophage cell model; and (3) explore the potential application of AR809 in a fermented food product. The information obtained in this work should be of interest to the dairy industry, particularly with respect to producing a novel milk-based fermented food product for use as a probiotic for the oropharyngeal mucosa.

\section{MATERIALS AND METHODS}

\section{Bacterial Strains and Culture Conditions}

Sixty-three Lactobacillus strains isolated from the oral cavity and pickles were stored at Shanghai Engineering Research Center of Food Microbiology. Isolate AR809 was from the oral cavity of a healthy individual and identified as Lactobacillus salivarius (GenBank accession number MK680189). Staphylococcus aureus was isolated from the oral cavity of a patient with pharyngitis. Streptococcus mutans ATCC 25135 was generously provided by Tongji Hospital (Shanghai, China).

The Lactobacillus strains were initially cultured on de Man, Rogosa, and Sharpe (MRS) medium (BD Biosciences, Heidelberg, Germany) in an anaerobic incubator $\left(85 \% \mathrm{~N}_{2}, 10 \% \mathrm{H}_{2}\right.$, and $5 \% \mathrm{CO}_{2}$; Thermo Fisher Scientific, Waltham, MA) at $37^{\circ} \mathrm{C}$ for $24 \mathrm{~h}$. The Staph. aureus strains were plated onto brain heart infusion (BHI) medium (BD Biosciences) and incubated overnight at $37^{\circ} \mathrm{C}$ under aerobic conditions. Streptococcus mutans was cultured in $\mathrm{BHI}$ broth at $37^{\circ} \mathrm{C}$ for $24 \mathrm{~h}$ in a $5 \% \mathrm{CO}_{2}$ atmosphere.

\section{Cell Culture}

For cell assays, FaDu cells and RAW264.7 cells were cultured in Dulbecco's modified Eagle medium (DMEM; HyClone, Logan, UT) containing 10\% (vol/ vol) fetal bovine serum (FBS; HyClone) and $100 \mathrm{U} /$ $\mathrm{mL}$ penicillin/streptomycin (Sigma-Aldrich, St. Louis, $\mathrm{MO})$ at $37^{\circ} \mathrm{C}$ under $5 \% \mathrm{CO}_{2}$. The medium was renewed every second day. Cells were subcultured once a week with a split ratio of $1: 3$ using $0.25 \%$ trypsin-EDTA solution (Sigma-Aldrich).

\section{Growth Inhibition Assay}

Agar-well diffusion assays (Abushelaibi et al., 2017) were used to evaluate inhibition of Staph. aureus by Lactobacillus strains. The Staph. aureus cultures (100 $\mu \mathrm{L}, 1 \times 10^{6} \mathrm{cfu} / \mathrm{mL}$ ) were plated onto the surface of a plate containing $20 \mathrm{~mL}$ of BHI agar. Six-mm-diameter wells were made in the BHI agar and filled with $100 \mu \mathrm{L}$ of cell-free culture supernatant from the 24-h Lactobacillus liquid culture (centrifuged at 8,000 $\times g$ for $10 \mathrm{~min}$ at $4^{\circ} \mathrm{C}$ ) that had been filtered using a $0.22-\mu \mathrm{m}$ filter. Sterilized MRS broth ( $\mathrm{pH}$ 7.0) was used as a negative control. The plates were incubated at $37^{\circ} \mathrm{C}$ for $24 \mathrm{~h}$ under aerobic conditions, and zones of inhibition were measured in millimeters.

An equal volume of cell-free supernatant was added into the BHI broth containing Staph. aureus cells $(1 \times$ $10^{6} \mathrm{cfu} / \mathrm{mL}$ ) and incubated at $37^{\circ} \mathrm{C}$ for $24 \mathrm{~h}$. Cells were washed 3 times with PBS ( $\mathrm{pH} 7.2$ ) and then stained with $50 \mu \mathrm{g} / \mathrm{mL}$ propidium iodide (Molecular Probes Inc., Eugene, OR) in PBS for 30 min in dark at room temperature. Cells were washed again, mounted on slides using mounting medium, and photographed with a fluorescence microscope (Leica, München, Germany). The dead Staph. aureus strains fluoresced red.

\section{Bacterial Adherence Assay}

The adhesion assay was determined according to the method of Wang et al. (2014), with minor modifications. A human epithelial cell line (FaDu) was obtained from the Shanghai Institutes for Biological Sciences, Chinese Academy of Sciences (Shanghai, China). Cells were seeded in 6-well tissue culture plates (Gibco, New York, NY) at $37^{\circ} \mathrm{C}$ under $5 \% \mathrm{CO}_{2}$. The medium in the wells was replaced with fresh medium until a monolayer formed with no more visible differentiation. Before adherence assays, the $\mathrm{FaDu}$ monolayer was 
washed twice with sterilized Dulbecco's PBS (DPBS). Lactobacillus strains were grown in MRS broth under anaerobic conditions at $37^{\circ} \mathrm{C}$ for $24 \mathrm{~h}$ and then labeled with fluorescein isothiocyanate (FITC; SigmaAldrich). Subsequently, $1 \mathrm{~mL}$ of FITC-labeled Lactobacillus suspension $\left(1 \times 10^{6} \mathrm{cfu} / \mathrm{mL}\right.$ in DMEM $)$ and 1 $\mathrm{mL}$ of antibiotic-free DMEM were added to each well containing $\mathrm{FaDu}$ cells and incubated at $37^{\circ} \mathrm{C}$ in a $5 \%$ $\mathrm{CO}_{2}$ atmosphere. After $2 \mathrm{~h}$ of incubation, cells were washed twice with DPBS, and examined using a multifunction microplate reader (Molecular Devices, Silicon Valley, CA). Lasers were set at $485 \mathrm{~nm}$ for excitation and $530 \mathrm{~nm}$ for emission. The adhesion percentage was calculated as follows: Adhesion index $(\%)=\left(\mathrm{B}_{1} / \mathrm{B}_{0}\right) \times$ 100 , where $\mathrm{B}_{0}$ and $\mathrm{B}_{1}$ are the initial and final fluorescence intensities of bacteria.

\section{Anti-Adherence Assays}

Adherence Exclusion. The inhibition of Staph. aureus adhesion by Lactobacillus strains was performed using the method of Esteban-Fernández et al. (2018) with modifications. The FaDu cells were seeded into 6 -well tissue culture plates and cultured until a monolayer of cells was formed in each well. The monolayer was washed twice with DPBS before the inhibition assay. One milliliter per well of Lactobacillus $\left(1 \times 10^{6} \mathrm{cfu} /\right.$ $\mathrm{mL}$ ) was first added and incubated for $2 \mathrm{~h}$. Unbound bacteria were removed, $1 \mathrm{~mL}$ per well of FITC-labeled Staph. aureus suspension $\left(1 \times 10^{6} \mathrm{cfu} / \mathrm{mL}\right)$ was added, and the mixture was incubated again for $4 \mathrm{~h}$. Cells plus bound bacteria were then detached with trypsinEDTA solution for $4 \mathrm{~min}$. The number of Staph. aureus adhered to $\mathrm{FaDu}$ cells was then determined as follows: Relative adherence of Staph. aureus $(\%)=\left(\mathrm{S}_{1} / \mathrm{S}_{2}\right) \times$ 100 , where $S_{1}$ and $S_{2}$ were the fluorescence intensities of Staph. aureus adhered in the presence and absence of Lactobacillus, respectively. Assays were performed in triplicate in 3 independent experiments.

Adherence Displacement. The displacement exclusion assay was explored as described above for the adherence exclusion assay except that the Staph. aureus suspension $\left(1 \times 10^{6} \mathrm{cfu} / \mathrm{mL}\right)$ was added before the Lactobacillus suspension $\left(1 \times 10^{6} \mathrm{cfu} / \mathrm{mL}\right)$. The displacement rate of pathogen was expressed as percentage adhesion (\%) of Staph. aureus in the presence and absence of Lactobacillus, as described for the exclusion assay.

Adherence Competition. The similar experimental protocol to the exclusion assay was used to analyze competitiveness between Lactobacillus and Staph. aureus. For competition assays, $1 \mathrm{~mL}$ of Lactobacillus strain suspension $\left(1 \times 10^{6} \mathrm{cfu} / \mathrm{mL}\right)$ and $1 \mathrm{~mL}$ of Staph. aureus suspension $\left(1 \times 10^{6} \mathrm{cfu} / \mathrm{mL}\right)$ were added simultaneously to each well and incubated for $4 \mathrm{~h}$. Com- petitiveness was calculated as the percentage adhesion (\%) of Staph. aureus in combination with Lactobacillus relative to Staph. aureus adhesion in the absence of Lactobacillus (control).

\section{Potential Probiotic Properties of L. salivarius AR809 in an Oral Cavity Model}

Acidic $p H$ and Bile Tolerance. Overnight cultures of AR809 $\left(1 \times 10^{6} \mathrm{cfu} / \mathrm{mL}\right)$ were inoculated at $3 \%(\mathrm{vol} /$ vol) into MRS broth with $\mathrm{pH}$ value adjusted to 2.0 , 3.0, 4.0, and 5.0 with $1.0 \mathrm{M} \mathrm{HCl}$ solution, or into MRS broth containing $0.5 \%$ and $1 \%$ (wt/vol) bile (Sangon Biotech, Shanghai, China), and incubated at $37^{\circ} \mathrm{C}$ for 24 h. Inoculated MRS broth (pH 6.5 and without bile) was used as control. Every $30 \mathrm{~min}$, the optical density value at $600 \mathrm{~nm}\left(\mathbf{O D}_{600 \mathrm{~nm}}\right)$ was measured using an automatic growth curve (Bioscreen C, Helsinki, Finland) analyzer after shaking the culture for $10 \mathrm{~s}$.

Resistance to Lysozyme and $\mathrm{H}_{2} \mathrm{O}_{2}$. Overnight cultures of AR809 $\left(1 \times 10^{6} \mathrm{cfu} / \mathrm{mL}\right)$ were inoculated at $3 \%$ (vol/vol) into MRS broth containing lysozyme (100 and $200 \mu \mathrm{g} / \mathrm{mL})$ or hydrogen peroxide $\left(\mathrm{H}_{2} \mathrm{O}_{2}, 0.08\right.$ and $0.8 \mathrm{mM}$; Sangon Biotech), and incubated at $37^{\circ} \mathrm{C}$ for $24 \mathrm{~h}$. Inoculated MRS broth without lysozyme and $\mathrm{H}_{2} \mathrm{O}_{2}$ was used as control. Every $30 \mathrm{~min}$, the $\mathrm{OD}_{600 \mathrm{~mm}}$ value was measured using the automatic growth curve analyzer after shaking for $10 \mathrm{~s}$.

Tooth Degradation. A tooth degradation assay was conducted according to the method of Nikawa et al. (2004). Ten-milligram hydroxyapatite samples (20 nm; Sigma-Aldrich) were placed in a 50-mL centrifuge tube, which contained $10 \mathrm{~mL}$ of BHI broth. The hydroxyapatite-BHI broth was filtered with a $0.22-\mu \mathrm{m}$ filter. The selected strain AR809 $\left(1 \times 10^{6} \mathrm{cfu} / \mathrm{mL}\right)$ was inoculated $(3 \%, \mathrm{vol} / \mathrm{vol})$ into each tube followed by incubation for $0,3,6,12,24$, and $48 \mathrm{~h}$ at $37^{\circ} \mathrm{C}$; Strep. mutans was used as a control. After each period of incubation, the amount of calcium released was measured by using a commercial kit (CA590; Leadman, Beijing, China) according to the manufacturer's instructions.

Antibiotic Susceptibility Testing. Antibiotic susceptibility of AR809 was determined using the disk diffusion method (Dolatabadi et al., 2018). First, MRS agar plates were overlaid with $50 \mu \mathrm{L}$ of overnight cultures of AR809 $\left(1 \times 10^{6} \mathrm{cfu} / \mathrm{mL}\right)$. Commercial antibiotic disks (ampicillin, kanamycin, norfloxacin, amoxicillin, chloramphenicol, nalidixic acid, erythromycin, minocycline, sulfamethoxazole, vancomycin, tetracycline, and clindamycin; Hangzhou Binhe Microorganism Reagent Co. Ltd., Hangzhou, China) were placed on the plates and incubated. After $24 \mathrm{~h}$ incubation at $37^{\circ} \mathrm{C}$, the diameter of inhibition zone was measured and expressed as susceptible (S), intermediate (I), or resistant (R) fol- 
lowing the instructions given by the manufacturer. All analyses were done in triplicate.

\section{In Vitro Functional Properties of L. salivarius AR809 in RAW264.7 Macrophage Cell Model}

Cytotoxicity Assay. The cytotoxicity of L. salivarius AR809 on murine macrophage RAW264.7 cells was assessed using the colorimetric 3-(4,5-dimethylthiazol2-yl)-2,5-diphenyltetrazolium bromide (MTT) assay (Esteban-Fernández et al., 2018). RAW264.7 cells were seeded in 96-well plates (Corning Inc., New York, NY) and then AR809 cells were added at different multiplicities of infection (MOI, bacteria:macrophages) of $0.2: 1,2: 1$, and 20:1 before co-incubation for $24 \mathrm{~h}$ at $5 \% \mathrm{CO}_{2}$. Subsequently, $20 \mu \mathrm{L}$ of MTT reagent (Sangon Biotech) diluted with sterilized DPBS $(5 \mathrm{mg} / \mathrm{mL})$ was added to each well and incubated for $4 \mathrm{~h}$ under the same conditions. After removal of the culture medium, $150 \mu \mathrm{L}$ of dimethyl sulfoxide was added to each well. The whole plate was oscillated at room temperature until formazan crystals were dissolved completely. Absorbance of each well at $570 \mathrm{~nm}$ was measured using a multi-function microplate reader. Cell viability was calculated using the following equation: Cell viability $(\%)=\left(\mathrm{A}_{\text {sample }} / \mathrm{A}_{\text {control }}\right) \times 100$, where $\mathrm{A}_{\text {sample }}$ is the absorbance of RAW264.7 cells co-incubated with Lactobacillus cells; and $\mathrm{A}_{\text {control }}$ is the absorbance of RAW264.7 cells alone (Huang et al., 2017).

Phagocytosis Assay. The phagocytic ability of RAW264.7 cells was investigated by neutral red uptake (Motlagh et al., 2015). Cells were seeded onto 96-well plates, treated without or with AR809 cells at an MOI of $2: 1$, and incubated at $37^{\circ} \mathrm{C}$ for $12 \mathrm{~h}$. Subsequently, $200 \mu \mathrm{L}$ of $0.075 \%$ neutral red solution (wt/vol) was added to the cell cultures. After incubation for $1 \mathrm{~h}, 200$ $\mu \mathrm{L}$ of cell lysate (ethanol and $0.01 \%$ acetic acid at the ratio of $1: 1, \mathrm{vol} / \mathrm{vol})$ was added to each well. Next, the mixtures were incubated at $4^{\circ} \mathrm{C}$ for $4 \mathrm{~h}$. The optical density was measured at $570 \mathrm{~nm}\left(\mathrm{OD}_{570 \mathrm{~nm}}\right)$ in a multifunction microplate reader. RAW264.7 cells treated with LPS $(1 \mu \mathrm{g} / \mathrm{mL}$; Sangon Biotech) and Staph. aureus (MOI 2) acted as positive controls. The phagocytic ability of cells pretreated with AR809 followed by LPS stimulation for $12 \mathrm{~h}$ was also assessed.

Anti-Inflammatory Activity in Macrophage Cells RAW264.\%. To determine the anti-inflammatory activity, RAW264.7 cells were treated with Staph. aureus (MOI 5) for $4 \mathrm{~h}$. After washing, the cells were incubated with Lactobacillus cells (MOI 2) for $24 \mathrm{~h}$ at $5 \% \mathrm{CO}_{2}$. The production of nitric oxide $(\mathrm{NO})$ was measured using the Griess reaction (Oh et al., 2018). The mRNA expression of cytokine genes TNFA, IL1B, IL10, nuclear factor-kappa B p65 (RELA), and induc-
Table 1. Primers used for reverse transcription $\mathrm{PCR}^{1}$

\begin{tabular}{ll}
\hline Gene symbol & Primer sequence $\left(5^{\prime}-3^{\prime}\right)$ \\
\hline$T N F A$ & CACCCTTATTCTCGCTCAC \\
CCIB & CCGCTTACAGTTCCTCT \\
& CTCGTGCTGTCGGACCCAT \\
CAGGCTTGTGCTCTGCTTGTGA & TGGCCTTGTAGACACCTTGGTCTT \\
RELA & CAGAGAAGCATGGCCCAGAAATCA \\
NOS2 & GTATTGCTGTGCCTACCCGAAAC \\
ACTB & GAGCGAGTTGTGGATTGTC \\
& CCAGGAAGTAGGTGAGGG \\
& CTCTGCTCCTCCCTGTCC \\
\hline
\end{tabular}

${ }^{1}$ Top $=$ forward; bottom $=$ reverse.

ible nitric oxide synthase (NOS2) were determined with real-time quantitative PCR (RT-qPCR). Total mRNA was isolated from RAW264.7 cells using TRI Reagent RNA isolation Reagent (Sigma-Aldrich) according to the manufacturer's instructions and cDNA was prepared using the iScript cDNA synthesis kit (BioRad, Hercules, CA). The RT-qPCR reaction was performed on a LightCycler Nano thermal cycler (Roche Applied Science, Penzberg, Germany), using SYBR Green FastStart kit (Roche, Basel, Switzerland). The PCR cycles were as follows: 1 cycle of $50^{\circ} \mathrm{C}$ for $2 \mathrm{~min}, 1$ cycle of $95^{\circ} \mathrm{C}$ for $10 \mathrm{~min}$, followed by 40 cycles of $95^{\circ} \mathrm{C}$ for $15 \mathrm{~s}$ and $60^{\circ} \mathrm{C}$ for $1 \mathrm{~min}$. The primers were used as shown in Table 1. Relative expression was calculated using the $2^{-\Delta \Delta \mathrm{Ct}}$ method, where $\mathrm{Ct}$ is the cycle threshold.

\section{Skim Milk Fermentation with AR809}

Effect of Sugars on AR809 Growth. Strain AR 809 was cultivated at $37^{\circ} \mathrm{C}$ in MRS broth. The growth curves of AR809 were determined with 96-well microtiter plates using the automatic growth curve analyzer to measure growth in MRS broth supplemented with $2 \%$ (wt/vol) of the following sugars (Sigma-Aldrich): glucose, fructooligosaccharides, lactose, sucrose, galactose, xylooligosaccharide, or oligomeric isomaltose.

Acidification Curves and Apparent Viscosity of Fermented Skim Milk. An overnight culture of AR809 was inoculated $(2.5 \%, \mathrm{vol} / \mathrm{vol})$ into skim milk supplemented with $2 \%$ (wt/vol) fructooligosaccharides or sucrose. After $24 \mathrm{~h}$ of fermentation at $42^{\circ} \mathrm{C}$, acidification curves were determined using a $\mathrm{pH}$ meter recorder (Mettler-Toledo, Zurich, Switzerland), and apparent viscosity (expressed in $\mathrm{mPa} \cdot \mathrm{s}$ ) was measured using a Discovery Hybrid Rheometer-3 (TA Instruments, New Castle, DE; $25^{\circ} \mathrm{C}$, shear rate profile of $100 \mathrm{~s}^{-1}$ ).

Inhibition of Staph. aureus Growth by Fermented Skim Milk. Antimicrobial effects of the supernatant of fermented skim milk were tested against 
Staph. aureus using the agar well diffusion method. First, $100 \mu \mathrm{L}$ of Staph. aureus culture $\left(1 \times 10^{6} \mathrm{cfu} / \mathrm{mL}\right)$ was plated onto the surface of a plate containing 20 $\mathrm{mL}$ of BHI agar. Then, 6 -mm-diameter wells were uniformly bored in the BHI agar, and $100 \mu \mathrm{L}$ of fermented skim milk supernatant $(6,000 \times g$ for 15 min $)$ was dispensed into each well. Plates were incubated at $37^{\circ} \mathrm{C}$ for $24 \mathrm{~h}$. After incubation, inhibition zone diameters surrounding each agar well were measured. Inhibition was considered positive when the zone diameter was $>6 \mathrm{~mm}$.

\section{Statistical Analyses}

All experiments were performed at least 3 times. The data shown are representative results of triplicate experiments and are presented as means \pm standard deviations. Data analysis was carried out with SPSS 22.0 software (SPSS Inc./IBM Corp., Armonk, NY), and Duncan's test was used to detect differences $(P<$ $0.05)$.

\section{RESULTS}

\section{Inhibition of Staph. aureus Growth by Lactobacillus Strains}

Lactobacillus plantarum AR113, L. plantarum AR195, and L. salivarius AR809 showed different levels of inhibition against Staph. aureus by the agar well diffusion method (Figure 1, inset figures a-d). Strain AR809 exhibited higher inhibition of Staph. aureus, with inhibition zone diameters of $24.6 \mathrm{~mm}$ (Figure 1b). Fluorescence microscopy showed that most of the Staph. aureus in the culture medium (control group) were alive (Figure 1A) and results were significantly different $(P<0.05)$ from those in the experiment group (Figure 1B-D). Dead bacteria dominated in the experiment groups. Thus, the selected Lactobacillus strains inhibited the growth of Staph. aureus.

\section{Adherence of Lactobacillus Strains to FaDu Cells}

The adherence indices of Lactobacillus strains to FaDu epithelial cell layer demonstrated that the strains did not have similar adhesion abilities. Strains AR113 and AR195 manifested poor adhesion, from 4.44 to 8.28\%, whereas AR809 exhibited higher adherence to $\mathrm{FaDu}$ cells, with an adhesion index of $31.1 \%$.

\section{Anti-Adhesive Effects on Adherence of Staph. aureus to FaDu Cells}

The ability of Lactobacillus strains to prevent Staph. aureus from binding to $\mathrm{FaDu}$ cell monolayers was eval- uated using exclusion, competition, and displacement assays. The adhesion of Staph. aureus to FaDu without interference by Lactobacillus was assigned as 100\%. As shown in Figure 2, Staph. aureus adhesion was reduced significantly in the presence of Lactobacillus strains AR809 and AR195 in all assays. In the exclusion assay, AR809 exhibited higher inhibition against adherence of Staph. aureus in contrast to strains AR113 and AR195, resulting in a notable reduction (47\%) in Staph. aureus adherence. In competition and displacement assays, AR809 also showed marked antagonistic effects, with the adhesion rate of Staph. aureus to FaDu cells reduced by $22.63 \%$ and $16.91 \%$, respectively. The 3 assays demonstrated that AR809 reduced the adherence of Staph. aureus more significantly than did competition and displacement assays. Therefore, AR809 was selected as the potential probiotic for further trials.

\section{Probiotic Properties of AR809 in an Oral Cavity Model}

Resistance to Acidic pH, Bile, Lysozyme, and $\mathrm{H}_{2} \mathrm{O}_{2}$. To maintain activity and viability through the oropharyngeal tract, a potential probiotic should be resistant to the extreme conditions of the oropharyngeal tract. Figure 3A shows that AR809 could survive at low $\mathrm{pH}$ and under a high concentration of bile salts. Moreover, AR809 could tolerate a wide range of acidic $\mathrm{pH}(3-5)$ but growth declined sharply at $\mathrm{pH} 2$. Strain AR809 showed comparatively better tolerance when exposed to $0.5 \%$ bile than at $1 \%$ bile. In addition, AR 809 exhibited good tolerance to $200 \mu \mathrm{g} / \mathrm{mL}$ lysozyme and $0.8 \mathrm{mM} \mathrm{H}_{2} \mathrm{O}_{2}$ (Figure 3B). Thus, AR809 could overcome the hostile conditions in the oropharyngeal tract and subsequently colonize the oropharyngeal tract.

Tooth Degradation. Figure 4 shows that the effect of Strep. mutans on calcium release from hydroxyapatite was negligible within the first $12 \mathrm{~h}$ of incubation but then increased strongly during the rest of incubation. After $48 \mathrm{~h}$ of incubation, calcium released from hydroxyapatite caused by Strep. mutans was $2.0 \mu \mathrm{g} /$ $\mathrm{mL}$. In contrast, calcium release by AR809 was almost negligible $(0.06 \mu \mathrm{g} / \mathrm{mL})$ after $48 \mathrm{~h}$ of incubation, suggesting good potential protection against tooth degradation.

Antibiotic Susceptibility. The susceptibilities of AR809 toward 12 antibiotics are presented in Table 2. Strain AR809 was resistant to kanamycin, norfloxacin, chloramphenicol, nalidixic acid, vancomycin, and tetracycline and had intermediate resistance to ampicillin, sulfamethoxazole, and clindamycin. In addition, AR809 was susceptible to amoxicillin, erythromycin, and minocycline, antibiotics that interrupt either protein biosynthesis or cell wall biosynthesis in the bacteria. 
In Vitro Functional Properties of AR809 in RAW264.7 Macrophage Cell Model

Cytotoxicity Assay. To understand the possible cytotoxic effect of AR809 on RAW264.7 macrophages, we evaluated the viability of RAW264.7 macrophage cells in the presence of viable AR809 at certain MOI $(0.2,2$, and 20). As shown in Figure 5A, no significant changes in cell viability were observed with AR809 at different MOI after $12 \mathrm{~h}$ of incubation. However, AR809 showed more than $120 \%$ cell viability after 24 $\mathrm{h}$ of incubation at an MOI of 0.2 . In contrast, AR809 had no cytotoxic effect on RAW264.7 cells at an MOI of 2 , similar to that of untreated macrophage cells, and a low cytotoxic effect was shown in AR809 at an MOI of 20 ( $\sim 11 \%$ dead cells).

Phagocytosis Assay. As shown in Figure 5B, the phagocytic activity of RAW264.7 cells induced by AR809 was significantly higher than that without AR809 or with Staph. aureus. This suggested that AR809 had a greater ability to activate the macrophages than Staph. aureus. The phagocytic activity of the macrophages triggered by AR809 might be effective in activating immune cells. Stimulation of RAW264.7 cells with LPS for $12 \mathrm{~h}$ led to a substantial increase in phagocytosis $(P<0.05)$. The percentage of macrophages to phagocytose neutral red increased from 12.58 to $68.05 \%$ following LPS stimulation. However,
A

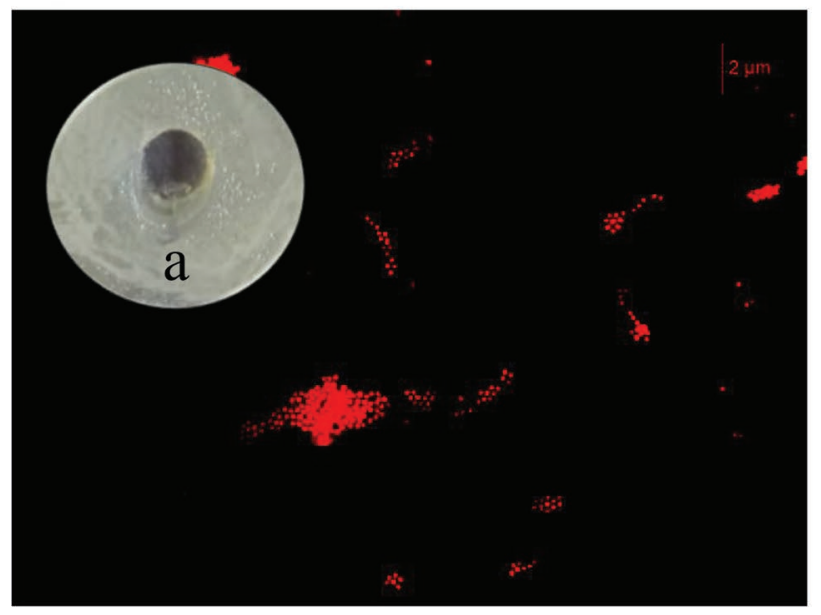

C

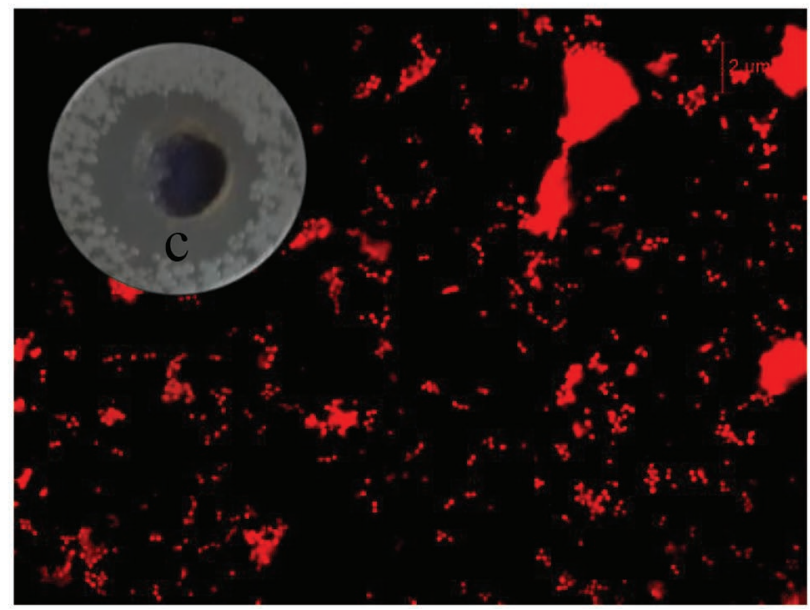

B

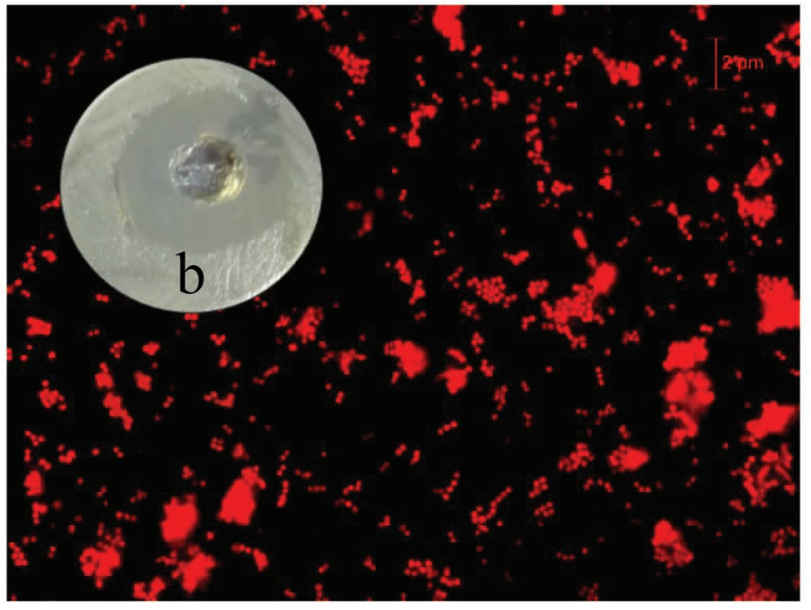

$\mathrm{D}$

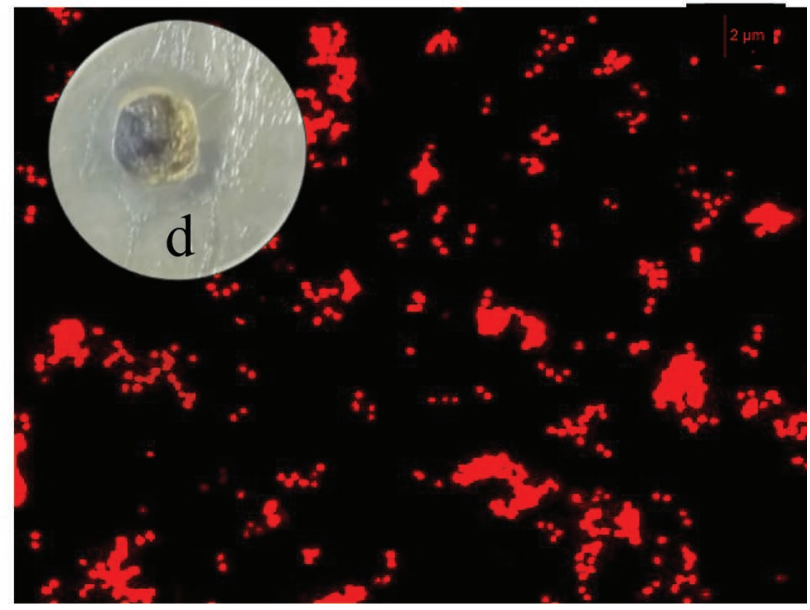

Figure 1. Effects of Lactobacillus strains on the growth of Staphylococcus aureus. The antimicrobial activities of the Lactobacillus strains were tested using fluorescence microscopy (panels A-D) and the agar well diffusion method (inset figures a-d). Dead Staph. aureus fluoresced red. A, a = control group (culture medium only); B, b = Lactobacillus salivarius AR809; C, c = Lactobacillus plantarum AR113; and D, d = L. plantarum AR195. 
phagocytosis was reduced to $39.73 \%$ in LPS-stimulated RAW264.7 cells pretreated with AR809.

Anti-Inflammatory Activity. To compare the anti-inflammatory activity of AR809 in Staph. aureusstimulated RAW264.7 cells, we measured the amount of the key inflammatory mediators NO, cytokines (TNFA, IL1B, and IL10), RELA, and NOS2 produced by treatment with AR809. As demonstrated in Figure $5 \mathrm{C}$, the production of $\mathrm{NO}$ in RAW 264.7 cell culture (control) was $5.19 \mu M$, whereas that stimulated with AR809 was $11.9 \mu M$. After treatment with Staph. aureus for $4 \mathrm{~h}$, the NO concentration in the supernatant increased compared with controls $(P<0.05)$. Strain AR809 decreased the NO level released from Staph. aureus-stimulated RAW264.7 and exhibited the strongest inhibition.

Figure 5D further demonstrated the effects of AR809 on gene expression of some upstream mediators (TNFA, IL1B, IL10, RELA, and NOS2) by RT-qPCR. As shown in Figure 5D, TNFA, IL1B, and NOS2 mRNA levels were all sharply increased by Staph. aureus treatment for $4 \mathrm{~h}$ but decreased by treatment with AR809 for 24 $\mathrm{h}$. The changes in gene expression confirmed the inhibition of Staph. aureus-induced inflammation by AR809 at the transcriptional level.

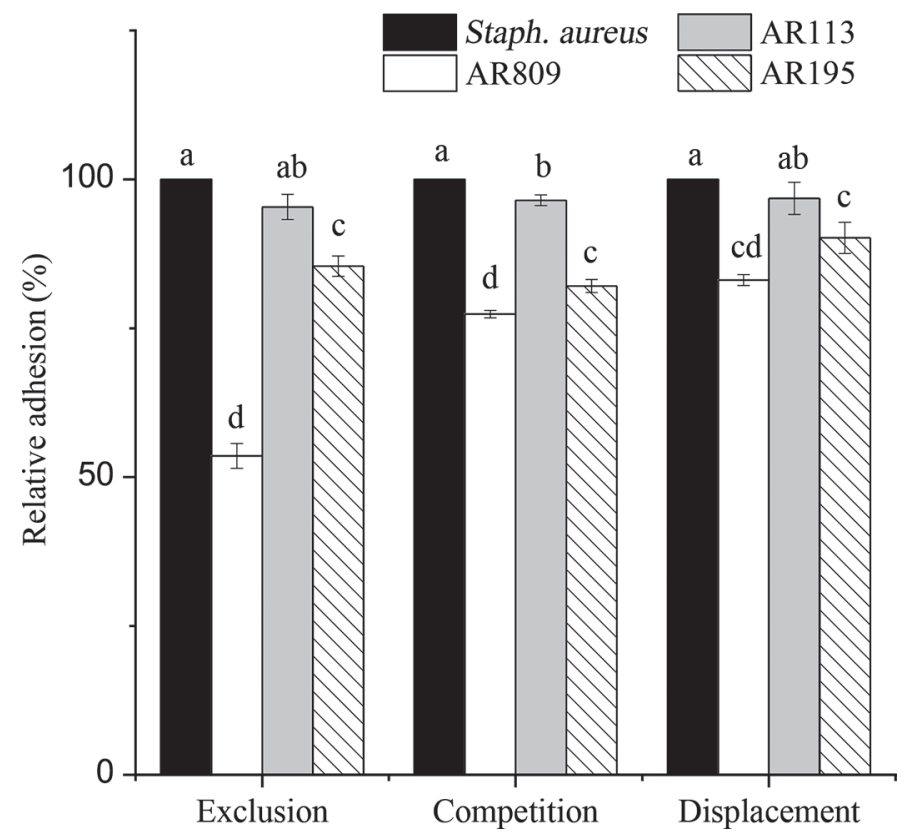

Figure 2. Effects of Lactobacillus strains (L. salivarius AR809, L. plantarum AR113, and L. plantarum AR195) on the adhesion behavior of Staphylococcus aureus to FaDu cells. Results are expressed as means $\pm \mathrm{SD}(\mathrm{n}=3)$. Means with different letters $(\mathrm{a}-\mathrm{d})$ differ significantly $(P<0.05)$.

\section{Fermentation of L. salivarius AR809 in Skim Milk}

The growth curves of AR809 with 7 types of carbohydrates in MRS medium are shown in Figure 6A. Strain AR809 grew best in the presence of glucose, sucrose, and fructooligosaccharides, followed by oligomeric isomaltose, xylooligosaccharide, galactose, and lactose. The $\mathrm{pH}$ of skim milk supplemented with $2 \%$ (wt/vol) sucrose or fructooligosaccharides with a $2.5 \%$ ( $\mathrm{vol} / \mathrm{vol}$ ) inoculum of AR809 decreased to 4.07 and 4.36, respectively (Figure 6B). Strain AR809 reached a viable cell count of $5.4 \times 10^{7} \mathrm{cfu} / \mathrm{mL}$ after $24 \mathrm{~h}$ of fermentation, indicating that it contributed to the acidification of skim milk. The apparent viscosity of skim milk with
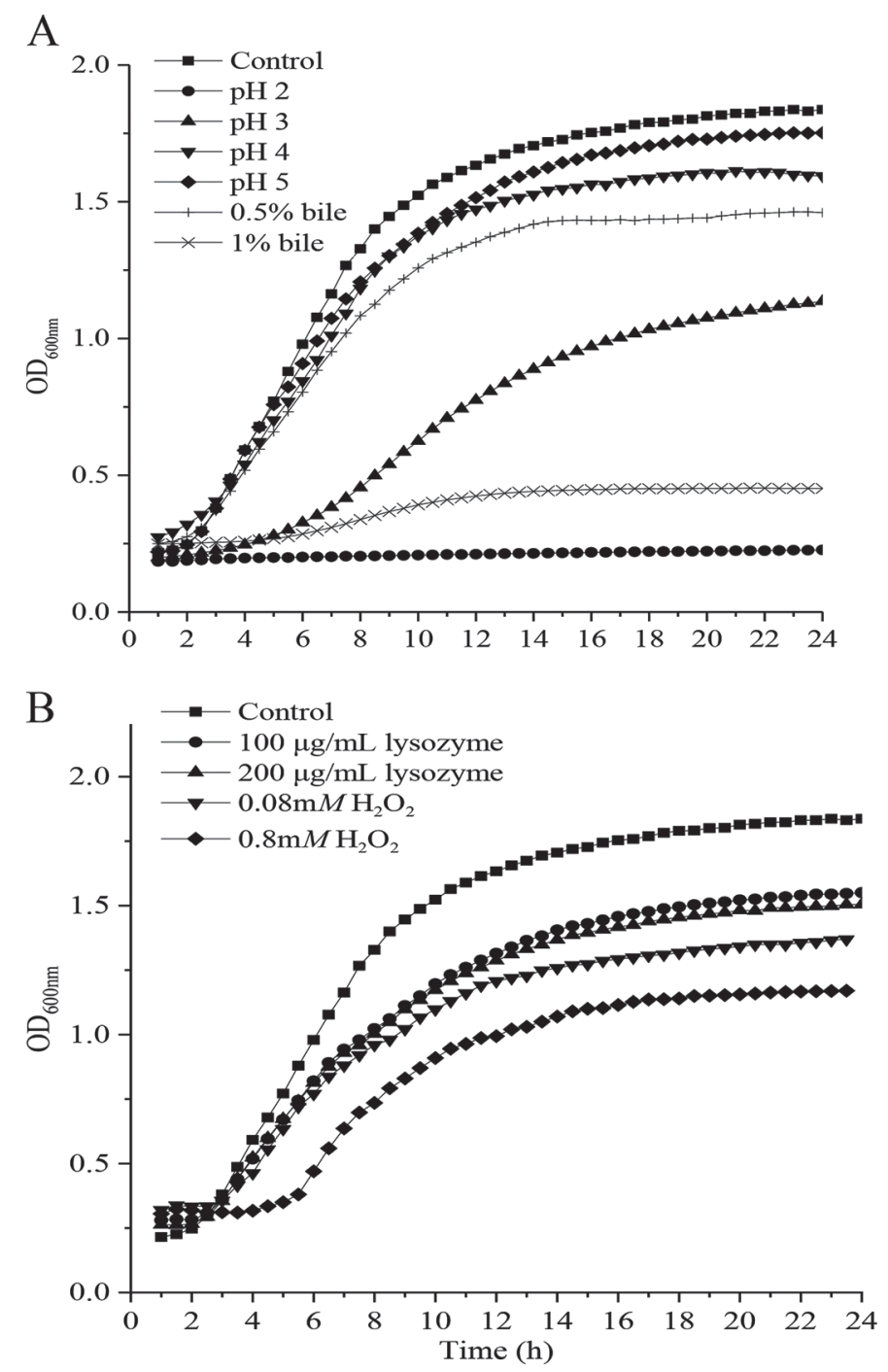

Figure 3. Growth curves of Lactobacillus salivarius AR809 versus incubation time under different conditions: (A) acidic $\mathrm{pH}$ and 0.5 or $1.0 \%$ bile; and (B) 100 or $200 \mu \mathrm{g} / \mathrm{mL}$ lysozyme and 0.08 or $0.8 \mathrm{mM}$ hydrogen peroxide $\left(\mathrm{H}_{2} \mathrm{O}_{2}\right)$. OD = optical density. 


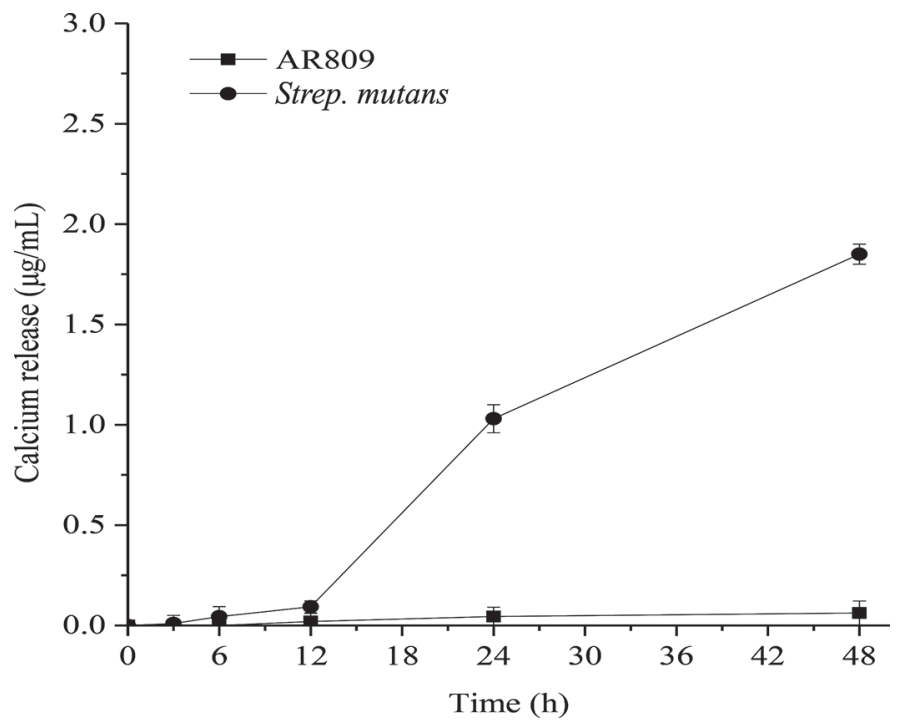

Figure 4. Effect of Lactobacillus salivarius AR809 on demineralization (calcium release from hydroxyapatite) of tooth enamel compared with Streptococcus mutans. Results are expressed as means \pm SD (n $=3$ ). After $48 \mathrm{~h}$ of incubation, calcium released from hydroxyapatite by Strep. mutans and AR 809 were 2.0 and $0.06 \mu \mathrm{g} / \mathrm{mL}$, respectively, indicating that AR809 has a good potential for protection against tooth degradation and could be a helpful aid to reduce risk of caries.

AR809 was increased $(5.85 \mathrm{mPa} \cdot \mathrm{s})$ compared with that of the control (1.18 $\mathrm{mPa} \cdot \mathrm{s}$; skim milk alone), and addition of $2 \%$ (wt/vol) fructooligosaccharides to the skim milk with AR809 further significantly increased viscosity, to $88.41 \mathrm{mPa} \cdot \mathrm{s}(P<0.05$; Figure $6 \mathrm{C})$. Moreover, AR809-fermented skim milk inhibited the growth of Staph. aureus in vitro, with inhibition zone diameters ranging from 8.7 to $12.6 \mathrm{~mm}$ (data not shown).

Table 2. Antibiotic susceptibility of Lactobacillus salivarius AR $809^{1}$

\begin{tabular}{lll}
\hline Antibiotic & $\begin{array}{l}\text { Dose } \\
(\mu \mathrm{g} / \text { disk })\end{array}$ & Sensitivity $^{2}$ \\
\hline Ampicillin & 10 & $\mathrm{I}$ \\
Kanamycin & 30 & $\mathrm{R}$ \\
Norfloxacin & 10 & $\mathrm{R}$ \\
Amoxicillin & 10 & $\mathrm{~S}$ \\
Chloramphenicol & 30 & $\mathrm{R}$ \\
Nalidixic acid & 30 & $\mathrm{R}$ \\
Erythromycin & 15 & $\mathrm{~S}$ \\
Minocycline & 30 & $\mathrm{~S}$ \\
Sulfamethoxazole & 25 & $\mathrm{I}$ \\
Vancomycin & 30 & $\mathrm{R}$ \\
Tetracycline & 30 & $\mathrm{R}$ \\
Clindamycin & 2 & $\mathrm{I}$ \\
\hline
\end{tabular}

${ }^{1}$ Dose values (dose of antibiotics on a standard antibiotic disk) are the mean of 3 experiments each with duplicates. Inhibition zone values (data not shown) were measured as means and then assigned to a sensitivity category (R, I, or S).

${ }^{2} \mathrm{~S}=$ susceptible; $\mathrm{I}=$ intermediate; $\mathrm{R}=$ resistant.

\section{DISCUSSION}

The aim of the initial part of this study was to screen antibacterial Lactobacillus strains with potential ability of inhibit adhesion of Staph. aureus to human oral epithelial cells. Of 63 Lactobacillus strains tested, 3 (AR809, AR113, and AR195) demonstrated high antimicrobial activity against Staph. aureus. A total of 6 Lactobacillus strains isolated from traditional pickles showed different antagonistic activity against Staph. aureus (data not shown). Compared with Lactobacillus strains isolated from traditional pickles, only 1 strain (L. salivarius AR809) isolated from a healthy oral cavity showed antagonistic activity against Staph. aureus. This finding indicates that it is not easy to screen antibacterial Lactobacillus strains isolated from a healthy oral cavity and that the antibacterial activity of Lactobacillus strains is closely related to their original source.

Adhesion to oral epithelium is among the main criteria for the selection of oral probiotic strains, because adequate host interaction is required for successful colonization of mucosal surfaces by probiotic bacteria and the resulting health benefits, including pathogen exclusion and stimulation of the mucosal immune system (Pérez Montoro et al., 2018). Because of the difficulties in studying bacterial adhesion in vivo, we used the $\mathrm{FaDu}$ cell model system in vitro to assess the adhesion rate of the selected Lactobacillus strains. Strain AR809 showed excellent adherence to $\mathrm{FaDu}$ cells (31.1\%), higher than previously published data in which adhesion ranged from 0.9 to $20 \%$ (García-Ruiz et al., 2014). Bacterial adhesion is initially based on nonspecific physical interactions between 2 surfaces, which then enable specific interactions between adhesions (usually proteins) and complementary receptors (Kiňová Sepová et al., 2018). Cell-wall proteomic approaches have provided insight into the molecular mechanisms involved in the adhesion process. Some of the cytoplasmic housekeeping proteins detected in the extracellular proteome have been defined as "moonlighting" proteins, including proteins involved in glycolysis, protein folding and stress response, as well as transcription and translation. These proteins can be found on the surface of Lactobacillus spp., where they act as adhesion-promoting factors (Pérez Montoro et al., 2018).

Adhesion to and invasion of host tissues are crucial steps in the pathogenesis of many pathogenic bacteria and viruses (Kakisu et al., 2013; Tsai et al., 2018). Several reports have confirmed that Lactobacillus effectively inhibits cell association and invasion by pathogens (Wang et al., 2014; Angmo et al., 2016). The competitive exclusion of adhesion of pathogens to host cells by adherent Lactobacillus cells is thought to be an important factor enabling Lactobacillus to inhibit 
A
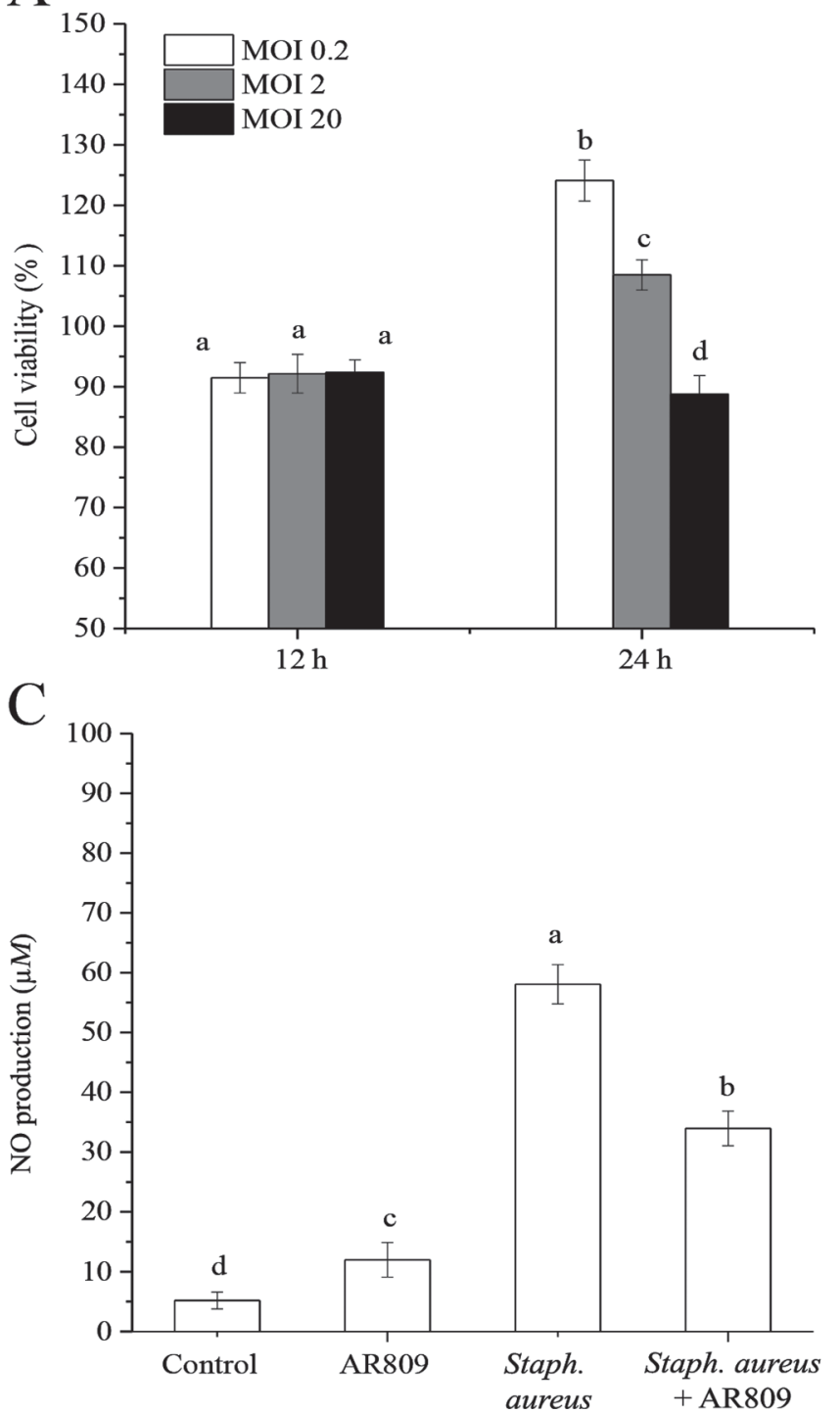

$\mathrm{B}$

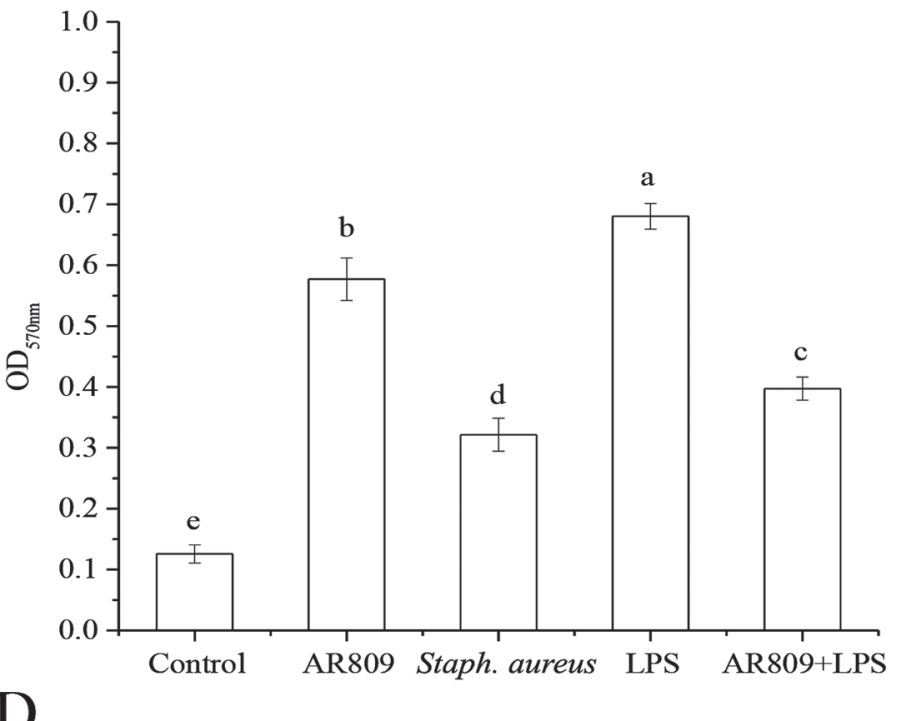

$\mathrm{D}$

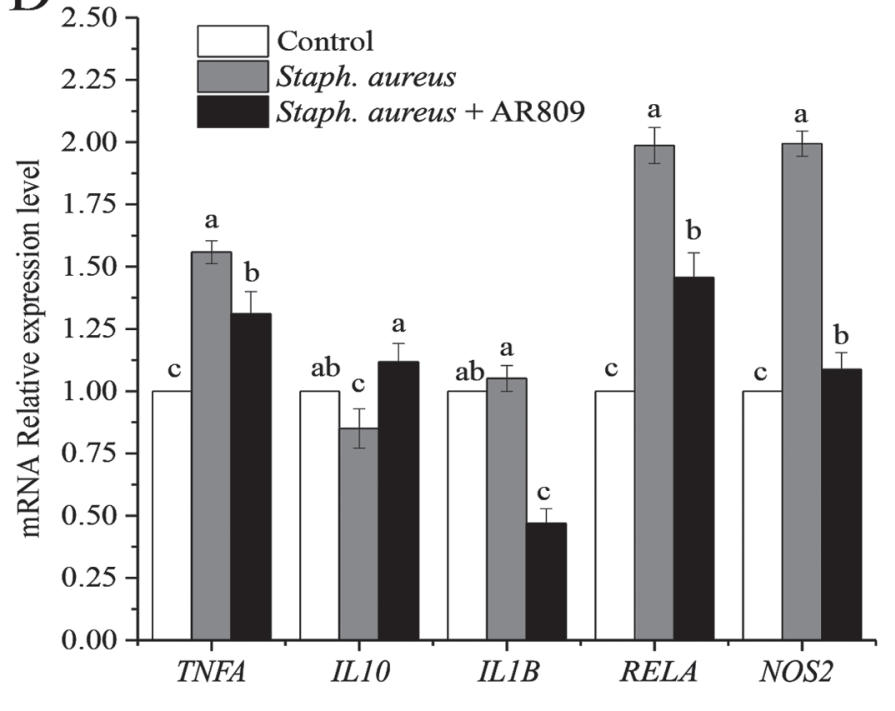

Figure 5. Effect of Lactobacillus salivarius AR809 on the function of RAW264.7 macrophage cells. (A) Effect of AR809 on proliferation of RAW264.7 cells at multiplicities of infection (MOI) of 0.2, 2, and 20; (B) effect of AR809, LPS, and Staphylococcus aureus on RAW264.7 phagocytosis; (C) production of NO in RAW264.7 macrophages treated with AR809 and Staph. aureus; and (D) gene expression of cytokines and inflammatory mediators in RAW264.7 macrophage cells. Results are expressed as means \pm SD $(n=3)$. Means with different letters (a-e) differ significantly $(P<0.05)$. OD $=$ optical density.

pathogen infection (Wang et al., 2014). In this work, the colonization resistance provided by AR809 against Staph. aureus was demonstrated in competition, exclusion, and displacement assays. These results suggested that AR809 protected the host epithelium by forming a barrier through self-aggregation and adherence mechanisms, and possibly against potential pathogen binding to host cell receptors and by co-aggregation with potential pathogens.

An ideal probiotic strain intended for any human use must be (a) of human origin, (b) devoid of potential virulence genes, (c) sensitive to common antibiotics, and (d) tolerant to oral, gastric, and intestinal physicochemical conditions; it should also be (e) catalasenegative, (f) able to adhere to epithelial membrane, and $(\mathrm{g})$ able to compete with other microbes (Nagpal et al., 2018). Our thorough screening for these characteristics allowed us to select a strain (AR809) possessing these desirable traits. This also explained why we selected AR809 isolated from the oral cavity with potential ability of adhesion and inhibition of adhesion of Staph. aureus to the pharyngeal epithelium as good candidate probiotic strain. In addition, because AR809 was isolated from the oral cavity, which often contains 

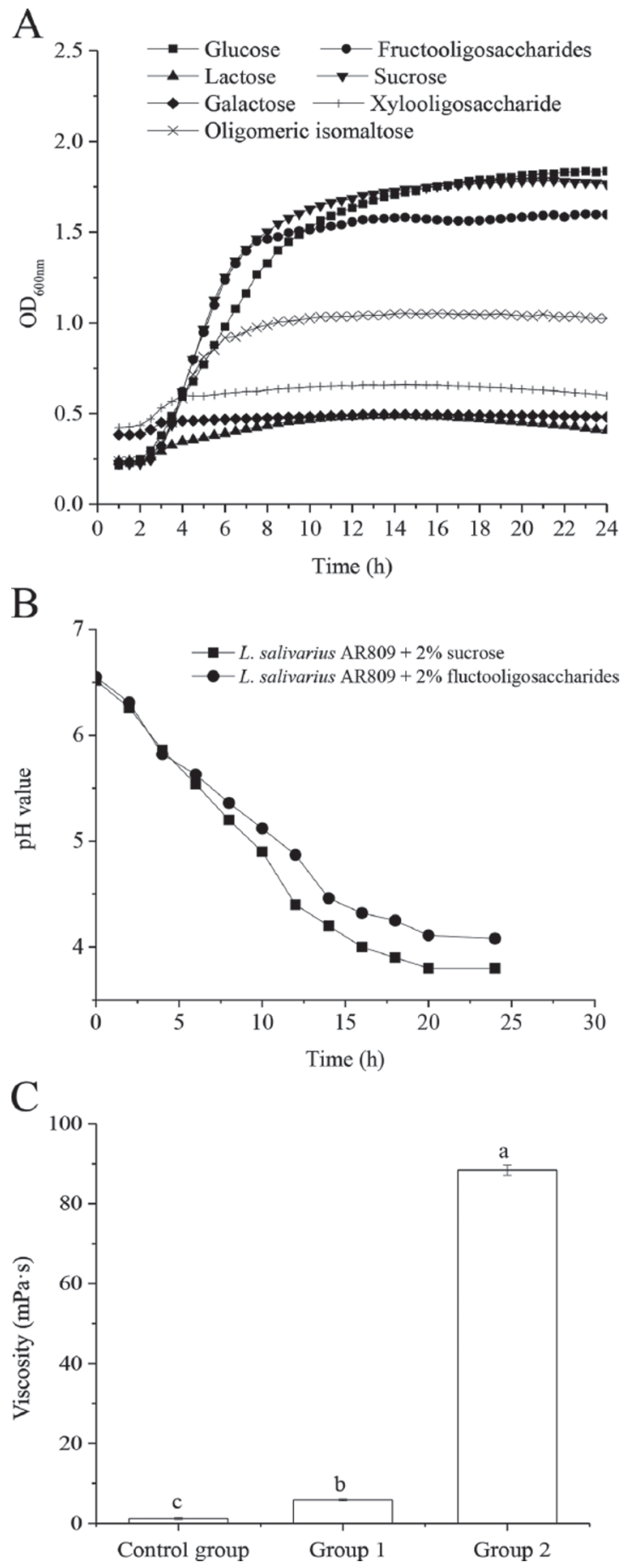

Figure 6. Optimized conditions for fermentation of skim milk by Lactobacillus salivarius AR809. (A) Growth curves of AR809 in de Man, Rogosa, and Sharpe medium supplemented with different carbon sources at 2\% (wt/vol); (B) pH change during fermentation by AR809 at $42^{\circ} \mathrm{C}$ in skim milk supplemented with $2 \%$ sucrose or fructooligosaccharides; and (C) apparent viscosities of AR809-fermented skim milks (shear rate $=100 \mathrm{~s}^{-1}$, temperature $=25^{\circ} \mathrm{C}$ ). Control $=$ skim milk, group $1=$ AR809-fermented skim milk, and group 2: AR809fermented skim milk supplemented with $2 \%$ (wt/vol) fructooligosaccharides. Results are expressed as means $\pm \mathrm{SD}(\mathrm{n}=3)$. Means with different letters $(\mathrm{a}-\mathrm{c})$ differ significantly $(P<0.05)$. OD $=$ optical density. complex bacteria and may have been exposed to longterm antibiotic treatments, it was likely to have resistance to some antibacterial drugs. A combination of AR809 and antibiotics may improve oral and intestinal health.

Lactobacillus has a strong ability to produce lactic acid or be resistant to acid. One study noted that a possible side effect of applying Lactobacillus to improve oral health is the increased risk of caries due to the production of lactic acid (Devine and Marsh, 2009). Therefore, we determined the ability of $L$. salivarius AR809 to degrade hydroxyapatite. The result showed that AR809 had only a slight ability to degrade hydroxyapatite after $48 \mathrm{~h}$ of culture. Nikawa et al. (2004) noted that Lactobacillus reuteri had low ability to degrade hydroxyapatite, and side effects were not reported when $L$. reuteri was administered to treat oral diseases. Based on the results of the clinical studies of Nikawa et al. (2004) and the current study, because of strain differences in acid production ability, AR809 had a higher ability to degrade hydroxyapatite than L. reuteri but much lower ability than Strep. mutans. Compared with Strep. mutans, AR809 has negligible ability to degrade hydroxyapatite and thus would not increase the risk of caries.

Strain AR809 induced proliferation of RAW264.7 macrophage cells and triggered their phagocytic activity. A primary function of macrophages is to phagocytize and degrade invading pathogens. However, weakened phagocytosis occurred due to the lack of a key phagocytic component to increase the susceptibility to bacterial infection. An important step for immunomodulation by probiotic Lactobacillus strain is enhanced phagocytic activity in the RAW264.7 cells (Jaffar et al., 2018). Activated macrophages might function to kill microbes (classical activation), produce extracellular matrix components for the promotion of wound healing (alternative activation), or secrete anti-inflammatory cytokines to terminate inflammation (Jaffar et al., 2018; Kaji et al., 2018). In this study, we demonstrated an effect of AR809 in phagocytic activity of macrophage cells to combat LPS and Staph. aureus cells. Strain AR809 not only had antimicrobial activity but also immunomodulation capacity and displayed significant inflammation suppression by enhancing production of IL-10 and inhibiting the expression of TNF- $\alpha$ and IL-1 $\beta$. Additionally, AR809 attenuated iNOS and repressed the nuclear transcription factor signaling pathway by impeding the nuclear translocation of $\mathrm{p} 65$.

The emerging demand for products having health benefits beyond nutrition has provided many opportunities to develop functional probiotic foods. In light of the in vitro probiotic and functional properties of 
AR809, we examined the possibility of co-cultivating the bacteria in bovine milk and potentially using AR809 in dairy products. We found that AR809 showed optimal growth in the presence of glucose, sucrose, and fructooligosaccharides. It survived in skim milk supplemented with $2 \%$ (wt/vol) fructooligosaccharides, resulted in acidification, and significantly increased the apparent viscosity of milk. These results indicate that AR809 could be used as a starter culture for fermented milk. Moreover, AR809-fermented skim milk could be used to inhibit the growth of Staph. aureus in vitro. Taken together, these data supported the potential of using AR809 to ferment milk for the production of a novel food product.

\section{CONCLUSIONS}

We isolated antibacterial strain L. salivarius AR809 from the oral cavity and demonstrated that this strain has potential ability to adhere to the pharyngeal epithelium and modulate the immune response; thus, it is a good candidate probiotic strain for improving oral health. Because of its unique probiotic and functional properties, L. salivarius AR809 has the potential to enhance the immunity of the human oropharyngeal tract against invading pathogenic microbes for the prevention and treatment of pharyngeal infections. Moreover, AR809 has potential as a probiotic in health-promoting foods. It can be widely used in various commercial food products such as fermented milk. Using such foods as the delivery vehicle for probiotics leads to increased demand for these traditional products, indirectly improving the local and national economies. Before commercial application, further investigations may be warranted to elucidate the potential beneficial effects of fermented milk containing AR809 both in vitro and in vivo.

\section{ACKNOWLEDGMENTS}

This work was supported by National Key Research and Development Program of China (grant no. 2018YFD0501600), the National Science Foundation (grant no. 31771956), and Shanghai Engineering Research Center of Food Microbiology (grant no. 19DZ2281100). We are grateful to the Department of Otolaryngology, Tongji Hospital, Tongji University (Shanghai, China) for technical support. The authors declare that they have no conflicts of interest.

\section{REFERENCES}

Abushelaibi, A., S. Al-Mahadin, K. El-Tarabily, N. P. Shah, and M. Ayyash. 2017. Characterization of potential probiotic lactic acid bacteria isolated from camel milk. Lebensm. Wiss. Technol. 79:316-325. https://doi.org/10.1016/j.lwt.2017.01.041.

Ai, R., J. Wei, D. Ma, L. Jiang, H. Dan, Y. Zhou, N. Ji, X. Zeng, and Q. Chen. 2017. A meta-analysis of randomized trials assessing the effects of probiotic preparations on oral candidiasis in the elderly. Arch. Oral Biol. 83:187-192. https://doi.org/10.1016/j.archoralbio .2017.04.030

Allaker, R. P., and A. S. Stephen. 2017. Use of probiotics and oral health. Curr. Oral Health Rep. 4:309-318. https://doi.org/10 .1007/s40496-017-0159-6.

Amer, A., S. Galvin, C. M. Healy, and G. P. Moran. 2017. The microbiome of potentially malignant oral leukoplakia exhibits enrichment for Fusobacterium, Leptotrichia, Campylobacter, and Rothia species. Front. Microbiol. 8:2391.

Angmo, K., A. Kumari, Savitri, and T. C. Bhalla. 2016. Probiotic characterization of lactic acid bacteria isolated from fermented foods and beverage of Ladakh. Lebensm. Wiss. Technol. 66:428 435. https://doi.org/10.1016/j.lwt.2015.10.057.

Blasco-Baque, V., L. Garidou, C. Pomié, Q. Escoula, P. Loubieres, S. Le Gall-David, M. Lemaitre, S. Nicolas, P. Klopp, A. Waget, V. Azalbert, A. Colom, M. Bonnaure-Mallet, P. Kemoun, M. Serino, and R. Burcelin. 2017. Periodontitis induced by Porphyromonas gingivalis drives periodontal microbiota dysbiosis and insulin resistance via an impaired adaptive immune response. Gut 66:872-885. https://doi.org/10.1136/gutjnl-2015-309897.

Devine, D. A., and P. D. Marsh. 2009. Prospects for the development of probiotics and prebiotics for oral applications. J. Oral Microbiol 1:1949. https://doi.org/10.3402/jom.v1i0.1949.

Dolatabadi, S., H. N. Moghadam, and M. Mahdavi-Ourtakand. 2018 Evaluating the anti-biofilm and antibacterial effects of juglans regia L. extracts against clinical isolates of Pseudomonas aeruginosa Microb. Pathog. 118:285-289. https://doi.org/10.1016/j.micpath .2018.03.055.

Esteban-Fernández, A., I. Zorraquín-Peña, M. D. Ferrer, A. Mira, B. Bartolomé, D. González de Llano, and M. V. Moreno-Arribas. 2018. Inhibition of oral pathogens adhesion to human gingival fibroblasts by wine polyphenols alone and in combination with an oral probiotic. J. Agric. Food Chem. 66:2071-2082. https://doi .org/10.1021/acs.jafc.7b05466.

Fan, X., B. A. Peters, E. J. Jacobs, S. M. Gapstur, M. P. Purdue, N. D. Freedman, A. V. Alekseyenko, J. Wu, L. Yang, Z. Pei, R. B. Hayes, and J. Ahn. 2018. Drinking alcohol is associated with variation in the human oral microbiome in a large study of American adults. Microbiome 6:59. https://doi.org/10.1186/s40168-018-0448 $-\mathrm{x}$.

FAO/WHO. 2006. Probiotics in food. Health and nutritional properties and guidelines for evaluation. Food and Nutrition Paper 85. Food and Agricultural Organization, Rome, Italy.

Gao, L., T. Xu, G. Huang, S. Jiang, Y. Gu, and F. Chen. 2018. Oral microbiomes: more and more importance in oral cavity and whole body. Protein Cell 9:488-500. https://doi.org/10.1007/s13238-018 -0548-1.

García-Ruiz, A., D. González de Llano, A. Esteban-Fernández, T. Requena, B. Bartolomé, and M. V. Moreno-Arribas. 2014. Assessment of probiotic properties in lactic acid bacteria isolated from wine. Food Microbiol. 44:220-225. https://doi.org/10.1016/j.fm .2014.06.015.

Huang, J. Y., C. Y. Kao, W. S. Liu, and T. J. Fang. 2017. Characterization of high exopolysaccharide-producing Lactobacillus strains isolated from mustard pickles for potential probiotic applications. Int. Microbiol. 20:75-84

Invernici, M. M., S. L. Salvador, P. H. F. Silva, M. S. M. Soares, R. Casarin, D. B. Palioto, S. L. S. Souza, M. Jr. Taba, A. B. Jr. Novaes, F. A. C. Furlaneto, and M. R. Messora. 2018. Effects of Bifidobacterium probiotic on the treatment of chronic periodontitis: A randomized clinical trial. J. Clin. Periodontol. 45:1198-1210.

Jaffar, N., T. Okinaga, T. Nishihara, and T. Maeda. 2018. Enhanced phagocytosis of Aggregatibacter actinomycetemcomitans cells by macrophages activated by a probiotic Lactobacillus strain. J. Dairy Sci. 101:5789-5798. https://doi.org/10.3168/jds.2017-14355. 
Kaji, R., J. Kiyoshima-Shibata, S. Tsujibe, M. Nanno, and K. Shida. 2018. Short communication: Probiotic induction of interleukin-10 and interleukin-12 production by macrophages is modulated by co-stimulation with microbial components. J. Dairy Sci. 101:28382841. https://doi.org/10.3168/jds.2017-13868.

Kakisu, E., P. Bolla, A. G. Abraham, P. de Urraza, and G. L. De Antoni. 2013. Lactobacillus plantarum isolated from kefir: protection of cultured Hep-2 cells against shigella invasion. Int. Dairy J. 33:22-26. https://doi.org/10.1016/j.idairyj.2013.06.004.

Keijser, B. J. F., T. J. van den Broek, D. E. Slot, L. van Twillert, J. Kool, C. Thabuis, M. Ossendrijver, F. A. van der Weijden, and R. C. Montijn. 2018. The impact of maltitol-sweetened chewing gum on the dental plaque biofilm microbiota composition. Front. Microbiol. 9:381.

Kiňová Sepová, H., B. Florová, A. Bilková, E. Drobná, and V. Březina. 2018. Evaluation of adhesion properties of lactobacilli probiotic candidates. Monatsh. Chem. 149:893-899. https://doi.org/10 .1007/s00706-017-2135-1.

Krzyściak, W., D. Kościelniak, M. Papież, P. Vyhouskaya, K. ZagórskaŚwieży, I. Kołodziej, B. Bystrowska, and A. Jurczak. 2017. Effect of a Lactobacillus salivarius probiotic on a double-species Streptococcus mutans and Candida albicans caries biofilm. Nutrients 9:E1242. https://doi.org/10.3390/nu9111242.

Lamont, R. J., H. Koo, and G. Hajishengallis. 2018. The oral microbiota: Dynamic communities and host interactions. Nat. Rev. Microbiol. 16:745-759. https://doi.org/10.1038/s41579-018-0089-x.

Lin, T. H., C. H. Lin, and T. M. Pan. 2018. The implication of probiotics in the prevention of dental caries. Appl. Microbiol. Biotechnol. 102:577-586. https://doi.org/10.1007/s00253-017-8664-z.

López-López, A., A. Camelo-Castillo, M. D. Ferrer, Á. Simon-Soro, and A. Mira. 2017. Health-associated niche inhabitants as oral probiotics: the case of Streptococcus dentisani. Front. Microbiol. 8:379.

Motlagh, B. M., N. A. Ahangaran, and S. M. Froushani. 2015. Calcitriol modulates the effects of bone marrow-derived mesenchymal stem cells on macrophage functions. Iran. J. Basic Med. Sci. 18:672-676.

Nagpal, R., S. Wang, S. Ahmadi, J. Hayes, J. Gagliano, S. Subashchandrabose, D. W. Kitzman, T. Becton, R. Read, and H. Yadav. 2018. Human-origin probiotic cocktail increases short-chain fatty acid production via modulation of mice and human gut microbiome. Sci. Rep. 8:12649.

Nikawa, H., S. Makihira, H. Fukushima, H. Nishimura, Y. Ozaki, K. Ishida, S. Darmawan, T. Hamada, K. Hara, A. Matsumoto, T. Takemoto, and R. Aimi. 2004. Lactobacillus reuteri in bovine milk fermented decreases the oral carriage of mutans streptococci. Int. J. Food Microbiol. 95:219-223. https://doi.org/10.1016/j ijfoodmicro.2004.03.006.

Oh, N. S., J. Y. Joung, J. Y. Lee, and Y. Kim. 2018. Probiotic and anti-inflammatory potential of Lactobacillus rhamnosus 4B15 and Lactobacillus gasseri 4M13 isolated from infant feces. PLoS One 13:e0192021. https://doi.org/10.1371/journal.pone.0192021.
Pérez Montoro, B., N. Benomar, N. Caballero Gómez, S. Ennahar, P. Horvatovich, C. W. Knapp, E. Alonso, A. Gálvez, and H. Abriouel. 2018. Proteomic analysis of Lactobacillus pentosus for the identification of potential markers of adhesion and other probiotic features. Food Res. Int. 111:58-66. https://doi.org/10.1016/j .foodres.2018.04.072.

Rungsri, P., N. Akkarachaneeyakorn, M. Wongsuwanlert, S. Piwat, P. Nantarakchaikul, and R. Teanpaisan. 2017. Effect of fermented milk containing Lactobacillus rhamnosus SD11 on oral microbiota of healthy volunteers: A randomized clinical trial. J. Dairy Sci. 100:7780-7787. https://doi.org/10.3168/jds.2017-12961.

Schenck, L. P., M. G. Surette, and D. M. Bowdish. 2016. Composition and immunological significance of the upper respiratory tract microbiota. FEBS Lett. 590:3705-3720. https://doi.org/10.1002/ 1873-3468.12455.

Singh, S., R. Bhatia, A. Singh, P. Singh, R. Kaur, P. Khare, R. K. Purama, R. K. Boparai, P. Rishi, P. Ambalam, S. K. Bhadada, M. Bishnoi, J. Kaur, and K. K. Kondepudi. 2018. Probiotic attributes and prevention of LPS-induced pro-inflammatory stress in RAW264.7 macrophages and human intestinal epithelial cell line (Caco-2) by newly isolated Weissella cibaria strains. Food Funct. 9:1254-1264. https://doi.org/10.1039/c7fo00469a.

Son, S. J., J. H. Koh, M. R. Park, S. Ryu, W. J. Lee, B. Yun, J. H. Lee, S. Oh, and Y. Kim. 2019. Effect of the Lactobacillus rhamnosus strain GG and tagatose as a synbiotic combination in a dextran sulfate sodium-induced colitis murine model. J. Dairy Sci. 102:2844-2853. https://doi.org/10.3168/jds.2018-15013.

Taverniti, V., M. Minuzzo, S. Arioli, I. Junttila, S. Hamalainen, H. Turpeinen, D. Mora, M. Karp, M. Pesu, and S. Guglielmetti. 2012. In vitro functional and immunomodulatory properties of the Lactobacillus helveticus MIMLh5-Streptococcus salivarius ST3 association that are relevant to the development of a pharyngeal probiotic product. Appl. Environ. Microbiol. 78:4209-4216.

Tsai, C. C., T. M. Lai, P. P. Lin, and Y. M. Hsieh. 2018. Evaluation of lactic acid bacteria isolated from fermented plant products for antagonistic activity against urinary tract pathogen staphylococcus saprophyticus. Probiotics Antimicrob. Proteins 10:210-217.

Wang, G., Y. Zhao, F. Tian, X. Jin, H. Chen, X. Liu, Q. Zhang, J. Zhao, Y. Chen, and H. Zhang. 2014. Screening of adhesive lactobacilli with antagonistic activity against Campylobacter jejuni. Food Control 44:49-57. https://doi.org/10.1016/j.foodcont.2014.03.042.

Wescombe, P. A., M. Upton, K. P. Dierksen, N. L. Ragland, S. Sivabalan, R. E. Wirawan, M. A. Inglis, C. J. Moore, G. V. Walker, C. N. Chilcott, H. F. Jenkinson, and J. R. Tagg. 2006. Production of the lantibiotic salivaricin A and its variants by oral streptococci and use of a specific induction assay to detect their presence in human saliva. Appl. Environ. Microbiol. 72:1459-1466.

Zupancic, K., V. Kriksic, I. Kovacevic, and D. Kovacevic. 2017. Influence of oral probiotic Streptococcus salivarius K12 on ear and oral cavity health in humans: Systematic review. Probiotics Antimicrob. Proteins 9:102-110. 